REGARDS

SUR LEECONOMIE ALLEMANDE

BULLETIN ECONOMIQUE DU CRAC

\section{Regards sur l'économie allemande}

Bulletin économique du CIRAC

$97 \mid 2010$

Varia

\title{
Industries culturelles
}

PRIDDAT Birger P., Wirtschaft durch Kultur

\section{OpenEdition}

\section{Journals}

Édition électronique

URL : http://journals.openedition.org/rea/4161

DOI : $10.4000 /$ rea. 4161

ISBN : 978-2-8218-0890-4

ISSN : 1965-0787

\section{Éditeur}

CIRAC

\section{Édition imprimée}

Date de publication : 1 juillet 2010

Pagination : 36

ISSN : 1156-8992

\section{Référence électronique}

"Industries culturelles », Regards sur l'économie allemande [En ligne], 97 | juillet 2010, mis en ligne le 13

juillet 2010, consulté le 21 septembre 2020. URL : http://journals.openedition.org/rea/4161 ; DOI :

https://doi.org/10.4000/rea.4161

Ce document a été généré automatiquement le 21 septembre 2020.

(C) CIRAC 


\section{Industries culturelles}

PRIDDAT Birger P., Wirtschaft durch Kultur

\section{RÉFÉRENCE}

PRIDDAT Birger P., Wirtschaft durch Kultur, Metropolis-Verlag, Marbourg, 2009, 136

p.

L'auteur se propose ici de mettre en lumière les interactions entre l'art, la culture et l'économie. Considérant en premier lieu l'art en tant que ressource économique, il s'intéresse ensuite aux relations et interfaces entre d'une part la culture et l'économie, et de l'autre, l'art et l'économie. Ce faisant, il précise les formes culturelles et artistiques permettant une telle analogie. Il aborde ensuite le théâtre en tant que réseau et marché pour évoquer enfin Beethoven comme marchand de ses propres compositions. (sh) 